\section{Quem lê (mas não cita) ciência brasileira?}

\section{Who reads (but does not quote) Brazilian science?}

\section{Sr. Editor,}

Em ciência, ler é importante; dar o crédito aos trabalhos lidos é mandatório. Inserida num contexto de uma produção científica recente bastante aumentada e qualificada na área médica, a produção na área da psiquiatria tem aumentado em quantidade e qualidade no Brasil. É importante destacar o papel da Revista Brasileira de Psiquiatria como um catalisador deste processo. Juntamente com a produção regular, a RBP tem oportunizado a edição de suplementos como aquele publicado em 2003 sobre o estresse pós-traumático.

Everton Botelho Sougey, da Universidade Federal de Pernambuco, chama a atenção para um fenômeno inquietante: o número e a qualidade dos artigos publicados na área de psiquiatria não está se refletindo numa disposição dos autores nacionais em citarem a produção qualificada de autores brasileiros. Em psiquiatria, o ambiente e a sociedade contribuem de forma significativa para a patoplastia de diversas síndromes. O estresse pós-traumático é um exemplo disto. A presença da violência em ambiente doméstico e o aumento das taxas de violência e criminalidade como um todo na sociedade sugerem que condições próprias da sociedade brasileira influenciem a expressão psicopatológica das conseqüências do trauma. Uma contribuição importante neste sentido foi feita por Câmara Filho e Sougey. ${ }^{1-4}$ Entretanto, estas contribuições amplamente reconhecidas em congressos e publicações não foram citadas no suplemento sobre o estresse pós-traumático editado pela RBP e por mim, coordenado em 2003. Respeitando a política da revista, os editores não interferem no trabalho dos autores em particular. Entretanto, a reflexão sobre o tema sugere que uma busca proativa da citação de obras brasileiras deve ser perseguida. Mais que isto, nos currículos das residências e nos exames de qualificação, a importância da obra (livros e artigos) de autores nacionais talvez deva ser mais salientada. Isto é ainda mais evidente no caso de patologias como o estresse pós-traumático, onde a influência do ambiente é tão importante.

Flávio Kapczinski Pesquisador do Conselho Nacional de Desenvolvimento Científico e Tecnológico (CNPq), Brasil Laboratório de Psiquiatria Molecular e Programa de Transtorno Bipolar, Universidade Federal do Rio Grande do Sul (UFRGS), Porto Alegre (RS), Brasil

Financiamento: Inexistente

Conflito de interesses: Inexistente

\section{Referências}

1. Kapczinski F, Margis R. Transtorno de estresse pós-traumático: critérios diagnósticos. Rev Bras Psiquiatr. 2003;25(Supl 1):3-7.

2. Camara Filho JW. Transtorno de estresse pós-traumático: características clínicas e sócio-demográficas de pacientes vinculados ao sistema de saúde da Polícia Militar de Pernambuco [dissertação]. Recife: Universidade Federal de Pernambuco (UFPE); 1999.

3. Sougey EB, Camara Filho JW. Estupro e transtorno de estresse póstraumático: aspectos epidemiológicos e clínicos. J Bras Psiquiatr. 1999;48(12):547-53.

4. Camara Filho JW, Sougey EB. Transtorno de estresse pós-traumático: formulação diagnóstica e questões sobre comorbidade. J Bras Psiquiatr. 2001;23(4):221-8.

\section{ASC - What does it measure and predict?}

ASC - 0 que ele mensura e prevê?

Dear Editor,

Governmental anti-tobacco measures should be evidencebased. In order to become familiar with smokers' sociodemographic, biological and psychological characteristics, Gigliotti and Laranjeira undertook a study aiming at the analysis of habits, attitudes and beliefs of smokers in four major Brazilian cities. ${ }^{1}$ In order to permit comparisons with a similar study done in Europe by Fagerström et al., ${ }^{2}$ this research used the same methodology.

Fagerström et al. state that "without an anti-smoking climate (ASC) it is difficult for politicians and others to control the health consequences of tobacco smoking with different actions such as e.g. increased excise taxes or restricting smoking in public places". It is also stated that "the ASC may also influence the health care providers' behavior vis-à-vis smoking and smokers own wish to give up smoking". ${ }^{2}$

What is the ASC? According to Fagerström et al., it was defined using "experts from each of the countries to arrive at a common definition of an ASC". ${ }^{2}$ Later, Gigliotti and Laranjeira defined it as "the tendency of a population to quit smoking". ${ }^{1}$

Based on findings from ASC, in the results section of their article, the latter authors report that " $80.5 \%$ of smokers stated a desire to stop smoking". In the discussion section, they suggest that the factor that would most strongly influence future efforts to stop smoking was "concern about exposing children, family and friends to tobacco smoke". Although mentioning that "the idea of an ASC is quite complex, and the ASC thermometer instrument has not been tested for reliability and validity", it is concluded that "it is clear that the current level of anti-smoking consciousness creates a favorable climate in Brazil". ${ }^{1}$

Although recognizing that this kind of study is of utmost importance for evidence-based anti-tobacco policies, some caveats should be taken into account:

1) The absence of a content and construct validation of ASC cannot be minimized. Inter-judge agreement warrants only "educated common-sense".

2) Verbal responses do not always describe the truth; ${ }^{3}$ they depend on contingencies. People saying that they want to quit smoking is only such a verbal response. Every therapist knows that many patients describe verbally high motivation to change behaviors, but do everything but trying to change. Or should the statements against corruption by most congressmen taken as an evidence of a tendency to "quit" corrupt behaviors? 
Therefore, some conclusions should be drawn only after studies verify that the verbal statements measuring ASC predict reliably actual quitting attempts. Such studies have already been done in other areas. ${ }^{4}$

Ivan Mario Braun

Interdisciplinary Group of Alcohol and Drug Studies,

Psychiatry Institute and Department, Medical School, Universidade de São Paulo (USP), São Paulo (SP), Brazil

\section{References}

1. Gigliotti A, Laranjeira R. Habits, attitudes and beliefs of smokers in four Brazilian capitals. Rev Bras Psiquiatr. 2005;27(1):37-44.

2. Fagerstrom $\mathrm{K}$, Boyle P, Kunze M, Zatonski $\mathrm{W}$. The antismoking climate in EU countries and Poland. Lung Cancer. 2001;32(1):1-5.

3. Skinner BF. Verbal behavior. Acton, Mass.: Copley Publishing Group; 1992.

4. Weinstein ND, Kwitel A, McCaul KD, Magnan RE, Gerrard M, Gibons FX. Risk perceptions: assessment and relationship to influenza vaccination. Health Psychol. 2007;26(2):146-51. 